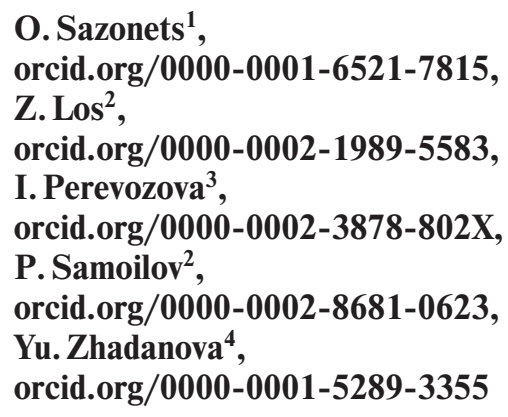

1 - University of Customs and Finance, Dnipro, Ukraine, e-mail: onsazonets@gmail.com

2 - National University of Water and Environmental Engineering, Rivne, Ukraine

3 - Ivano-Frankivsk National Technical Oil and Gas University, Ivano-Frankivsk, Ukraine

4 - O.S. Popov Odesa National Academy of Telecommunication, Odesa, Ukraine

\title{
LABOR AND ASSETS OPTIMIZATION IN THE CONTEXT OF INCREASING THE INTERNATIONAL INFORMATION COMPANY EFFICIENCY
}

Purpose. Research on the influence of factors of production on the efficiency of the information company.

Methodology. In the course of the research the following methods were applied: theoretical generalization (to cover the theoretical and methodological foundations of production functions), induction, deduction (to study corporations' activity), the systemic approach (to construct an algorithm for determining the optimal values of the average cost of a unit of fixed assets, current assets and average salary), graphic method (for the purpose of visual representation), mathematical modelling (to make a model of optimization of corporation's expenditures management).

Findings. Resulting from the application of the mathematical apparatus it was found out that to ensure maximum profit it is optimal for the information company to hold fixed assets worth 1125.83 hundred dollars with the payment for the personnel in the amount of 130.96 hundred dollars on average per a single specialist with indexation taken into account.

Originality. There has been suggested an algorithm for determining the optimal values of the average cost of a unit of fixed assets, current assets and average salary. There has been made a model of optimization of a corporation's expenditures management using the Cobb-Douglas production function and the theory of Lagrange multipliers. The analysis of the obtained dependence allows reaching the optimal value of these parameters under which the income function reaches the maximum.

Practical value. The presented methods for solving the problem can be used to increase the competitiveness of the company by determining the reserves for further improvement of the business.

Keywords: optimization, efficiency, production function, information company, multi-stage model

Introduction. Since the world financial system of corporations is undergoing change and is developing in the process of transnationalization of the world economy in the information and institutional environment, the problem of corporation's expenditures optimization can hardly be solved without studying and using the financial mechanism.

The important issue in the field of distribution, accumulation and preservation of the capital is the issue of the management of investments while they are being distributed into assets that is the application of the mechanism of the investment portfolio management which ensures preservation and accumulation of the funds in compliance with the dynamic market conditions under which a member of the economic system finds himself [1]. Under conditions of significant disproportions in the corporation's production capital structure in the information and institutional environment the Cobb-Douglas production function cannot be applied to manage productive resources irrespective of all its benefits. However, it can be used as an instrument of productive resources management analysis. The application of Cobb-Douglas function is not a new idea and can be referred to in a number of scientific papers $[2,3]$. However, in the present article we have attempted to develop rather a complex algorithm to determine the ways to increase the enterprise efficiency. It consists of transforming the values of company indicators into common logarithms, determining correlation coefficients, deriving a regression equation, transforming it into a Cobb-Douglas function, constructing a system of equations using Lagrange multipliers, and finding the optimal solution to improve the efficiency of the company.

Literature review. Factors of production are the main causes and conditions of production. The whole point of production lies in using production factors and creating economic products based on them. Thus, the factors of production are

(c) Sazonets O., Los Z., Perevozova I., Samoilov P., Zhadanova Yu., 2020 the driving force of production, the components of production potential. High quality of products ensures economical use of material and labor resources, stabilization of reproduction process, economic growth, proportionality and competitiveness, in the world market as well, and influences the efficiency of a particular enterprise's activity. The condition of the personnel of the enterprise, the level of its qualification and professionalism, the ability of hired employees to optimally solve assigned production tasks and to bring profit to the enterprise are directly dependent on theoretical approaches and practical methods of working with people. Undoubtedly, these factors affect the efficiency of the enterprise. The theory of factors of production relies, to a certain extent, on the use of mathematical, model apparatus, which are factor models in the form of mathematical dependence which links the value of the production result obtained to the values of production factors that led to the above result. Modern methods of expenditure management optimization which are used for planning and forecasting the maximization of income are due to the development of mathematical modeling. It should be pointed out that a great number of works of national and foreign scientists are dedicated to this subject. One of such methods is the method for using the Cobb-Douglas production function. The methods of its definition and application are described in the following research [4].

At present there is a large list of works devoted to the theory and practical application of the Cobb-Douglas function. [5] determined the possibility of using the Cobb-Douglas production function as a tool for managing the productive resources of the region. Costs are described as labor and fixed capital costs. Based on these factors, gross regional income is calculated. This method as applied for a specific company has been used in this article.

Application of the Cobb-Douglas production function leads to very good results, for example, when using this function in economic modeling along with the results of a simula- 
tion study. [2,6] developed the dependence of the value of the profit function of the two-resource enterprise on the values of elasticity of the production output. Using changes of these parameters, one can find the maximum of this function and estimate the sensitivity to oscillations. However, the conditions of our company are different from those presented by smaller fluctuations.

Significant contribution to the study on theoretical and applied aspects of the production function was made by a number of Ukrainian scholars [4, 7]. Their publications reveal the essence of the concept of "production function", they provide the characteristics of the advantages and disadvantages of using the Cobb-Douglas production function for the analysis and forecasting of production at both micro and macro levels. The advantages of this function are used in the study on microlevels (functioning of the information company).

Paper [3] suggest a mechanism that uses the Cobb-Douglas production function to solve the problem of compensation of time expenditures for quantitative explanation of cost sources from the point of view of the employment relationships and equipment. The target setting is close to ours. Aspects of equipment and labor force are crucial in today's production setup, but we have strengthened the solution to the problem discussed by using Lagrange multipliers.

Cheng and Han [8] established a modified model of the Cobb-Douglas production function; also the authors prepossessed an improved simulated annealing algorithm. They suppose this method is characterized by high precision and rapid convergence. It is suitable not for all terms of the company development.

Most authors emphasize the important role of optimization of cost management in corporations to ensure their profitability and the implementation of an effective innovative component $[9,10]$. Lagrange multiplier is established as a necessary and sufficient optimality condition for set-valued optimization problems and weakly minimal solutions of a constrained vector optimization problem [11, 12]. Having combined two methods - application of the Cobb-Douglas production function and Lagrange multipliers, we are presenting the solution to our problem for the information company.

Unsolved aspects of the problem. The lack of balance between the assets and the workforce of the information company requires further research using the Cobb-Douglas production function and Lagrange multipliers.

The purpose of the article is to improve the mechanisms of making a model of corporation's expenditures optimization to ensure the profitability of the corporation and to introduce an effective innovative component in the information and institutional environment taking into account the Cobb-Douglas production function in the conditions of political instability and progressive inflation.

Methods. The theoretical and methodological basis of the research is the fundamentals of information technologies in economics, scientific works of national and foreign scientists on maximizing gross income in the corporations' activities.

In the course of the research the following methods were applied: theoretical generalization (to cover the theoretical and methodological foundations of production functions), induction, deduction (to study corporations' activity of Rivnetelekombud LLC), the systemic approach (to construct an algorithm for determining the optimal values of the average cost of a unit of fixed assets, current assets and average salary), graphic method (for the purpose of visual representation), mathematical modeling (to make a model of optimization of corporation's expenditures management in the information and institutional environment).

At the same time, the questions of the theoretical and applied characteristics of modeling of corporation's expenditures management optimization in the information and institutional environment and the promotion of goods, works and services onto the market to the end user remain debatable and have not been fully studied. The developed scientific approaches to the selection and substantiation of management of productive resources of the enterprise have made it possible to establish the fact that at present the Cobb-Douglas production function is not being widely used in the practice of managing the corporation in the information and institutional environment. It makes the subject of the research topical and defines its goals and structure accordingly.

Results. Construction of an optimal solution algorithm. To study the efficiency of the corporation the authors suggested an algorithm for determining the optimal values of the average cost of a unit of fixed assets, the average cost of a unit of current assets and the average salary of workers of corporations, based on the effective management of the industrial resources of the corporation which is carried out according to the scheme: enterprise indicators - identification of correlation coefficients formulation of the regression equation - plotting of the Lagrange function - finding the optimal solution of the system of equations with transformation of Lagrange function - the optimal solution [13, 14]. The suggested algorithm (Fig. 1) allows analyzing and evaluating the risk avoidance when making managerial decisions in the conditions of continuous financial and economic changes at different stages of innovative development of the enterprise aimed at maximizing gross income.

Let us consider production functions from the point of view of production and economic practice - the correlation between productive resources that are being used (both material and human resources) and the products that are being manufactured. If we have $\mathrm{n}$ productive resources, the $i^{\text {th }}$ resources can be found by means of $x_{i}$. If $\mathrm{m}$ products are produced, then the number of the $j^{\text {th }}$ product is defined by means of $y_{j}$; as a result, we have come up with the following production function

$$
F(x, y, a)=0,
$$

where $a=\left(a_{1}, a_{2}, \ldots, a_{p}\right)$ is a production parameter vector.

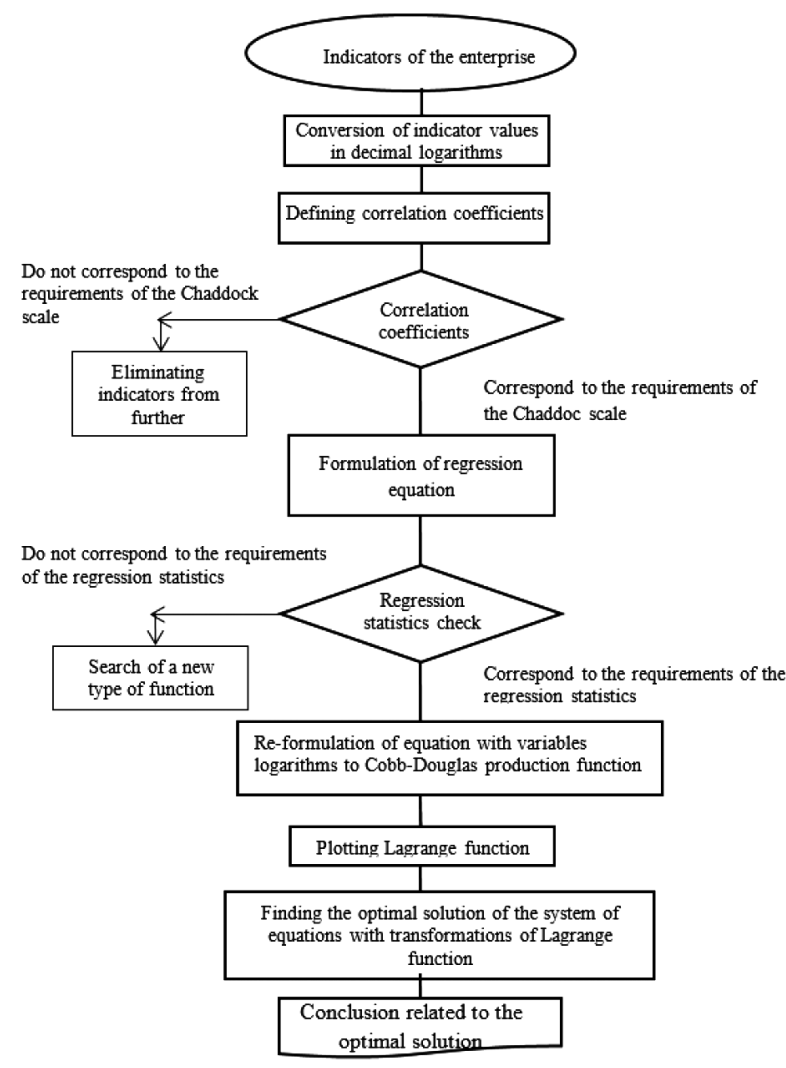

Fig. 1. Algorithm for determining the optimal values of the average cost of a unit of fixed assets, the current assets and the average salary of workers 
It should also be noted that the production function (1) can also be presented in the form of a table taking into account the length of the production cycle (considering the period between resource expenditures and production output). It is believed that the time of measurement of the current values of $x$ and y significantly exceeds the length of the production cycle.

Production resources $x$ vary by the ways they are spent in production processes. The resources of two types are usually considered: an object of labor (raw materials, components, and so on) and fixed assets (equipment, facilities, and others). The first type of resources is used in the process of production during the production cycle. The second type of resources requires more production cycles.

In production and economic practical activities, the following production functions are used. las).

Static, neoclassical production functions (Cobb-Doug-

$$
y=a_{0} x_{1}^{a_{1}} x_{2}^{a_{2}} x_{3}^{a_{3}} \ldots,
$$

where $y$ is the volume of production which is a scalar value; $a_{0}$, $a_{1}, a_{2}, a_{3}, \ldots$ are positive coefficients, parameters.

This function was first proposed by Knut Wicksell. In 1928, the function was verified based on statistics by Charles Cobb and Paul Douglas in the paper "Theory of Production" for production processes.

Production functions with constant elasticity of resources substitution (CES-functions) are

$$
y=b\left(\sum_{i=1}^{n} \beta_{i} x_{i}^{-p}\right)^{-\delta / \beta} .
$$

For two productive resources and $\delta=1$ we have

$$
y=b\left(\beta_{1} x_{1}^{-p}+\beta_{2} x_{2}^{-p}\right)^{-1 / \beta} .
$$

Production functions with constant proportions (Leontiev's functions)

$$
y=b \cdot \min \left\{\frac{x_{1}}{x_{1}^{0}}, \frac{x_{2}}{x_{2}^{0}}, \ldots, \frac{x_{n}}{x_{n}^{0}}\right\},
$$

where $b, x_{1}^{0}, x_{2}^{0}, \ldots, x_{n}^{0}$, are positive parameters.

It should be noted that the main difference of production functions of this type from the functions $(2-4)$ - is the rational structure of the productive resources which are imposed by means of the vector $x^{0}=\left\{x_{1}^{0}, x_{2}^{0}, \ldots, x_{n}^{0}\right\}$. If the resource vector corresponds to the correlation, then this function looks as follows

$$
x=t x^{0},
$$

where $t$ is a nonnegative scalar, the resources are used rationally and the production output is defined by the correlation $y=t b$.

Any deviation of the cost of resources from this structure leads to irrational use of part of the resources. There is another set of production functions: the linear function, the Allen function, the LES function, the Solow function, the linear programming function, and so on.

It should be noted that in practice the Cobb-Douglas function is more often used since it is the simplest of two-factor models $[15,16]$. If the function (2) is determined on reliable statistical information, then being extrapolated, it can also be used for prediction of, for example, the output depending on the consumption of planned resources at relatively short intervals of time or for planning the need in resources for a given volume of the output. By means of the formula (2) one can find models of production-economic objects from three resources

$$
y=a_{0} x_{1}^{a_{1}} x_{2}^{a_{2}} x_{3}^{a_{2}}
$$

where $x_{1}$ is disposal of fixed assets; $x_{2}$ is disposal of current assets; $x_{3}$ is disposal of human resources [17].

The popularity of this function among econometrics can be explained by its advantages [18]:

1. Non-linearity. The model is nonlinear - the dependence of the result on the cost has a nonlinear character, and therefore has no defects characteristic of linear production functions. Linear mathematical models describe linear processes that are not entirely realistic, imply the existence of the perfect competition, the absence of barriers to free pricing, suggest that the marginal products of production factors are equal to their prices, ignore changes in time. Models of linear programming find optimal solutions for the ideal economy, but in the real economy a number of hypotheses of the linear model are not confirmed. Therefore, linear models do not describe and analyze the economy exhaustively enough. Therefore, the results of calculations derived from the linear model should be used with caution or specify and correct using models of other types, statistical studies, etc.

2. Dynamism. The difference between reality and classical dynamic models (V.Leontiev, G. von Neumann, J.Timbergen, et al.) is so great that it can be stated that at present dynamic models have no practical application.

3. Simplicity. The function is simple, and therefore attractive for practical application in the management of productive resources.

Therefore, in our case, the description of the production process using the Cobb-Douglas function is the most suitable.

Construction of the Cobb-Douglas production function for the company. Let us consider the dependency between income and other variables for the company under research. The company's income is presented by means of the Cobb-Douglas production function

$$
Y=a_{0} K^{a_{1}} Q^{a_{2}} L^{a_{3}},
$$

where $Y$ is the company's income; $K$ is the average cost of a unit of fixed assets; $Q$ is the average cost of a unit of current assets; $L$ is an average salary; $a_{0}, a_{1}, a_{2}, a_{3}$ are coefficients (parameters).

To find the parameters $a_{1}, a_{2}, a_{3}$ we use the method of regression analysis. Taking into account the fact that there is a certain connection between the above parameters, their sum equals one. An important property of the resource elasticity coefficients of the Cobb-Douglas function: the sum of the coefficients of elasticity is equal to the index of the effect of scale expansion. If $a_{1}, a_{2}$ and $a_{3}$ exceed one, the production function has a growing effect from the scale of production (it means that if the values $K, Q, L$ increase in a certain proportion, the value $f(K, Q, L)$ increases in a larger proportion). If their sum equals one, the effect from the scale of production is said to be constant (the value $f(K, Q, L)$ increases in the same proportion as the values $K, Q, L$ ), or the level of resource efficiency does not depend on the scale of production. In the case where the sum of the parameters $a_{1}, a_{2}$ and $a_{3}$ is less than one, a decreasing effect from the scale of production is observed (the value $f(K, Q, L)$ increases in a smaller proportion than the values $K, Q$ and $L$ ) or with the expansion of the scale of production the average cost of resources per unit of output decreases. It should be noted that these properties do not depend on the numerical values of $K, Q$, and $L$ and are preserved at each point of the production function, that is, the coefficients $a_{1}, a_{2}$ and $a_{3}$ are constant and do not depend on the volume of the factors $K, Q$, and $L$.

To perform the correlation and regression analysis we transform the function (5) into linear dependence by means of a logarithmic operation.

To make calculations easier we transform function (5) into the following expression having made simplification

$$
Y=10^{\alpha_{0}^{*}} K^{\alpha_{1}} Q^{\alpha_{2}} L^{\alpha_{3}},
$$

where $a_{0}=10^{\alpha_{0}^{*}}$. 
Taking into account the complexity and scale of the calculations, to solve the problem we take the logarithm of both parts of the equation of the production function (6)

$$
\lg Y=\alpha_{0}^{*}+\alpha_{1} \lg K+\alpha_{2} \lg Q+\alpha_{3} \lg L .
$$

Based on the results of the calculations there was elaborated a new table of the data to calculate the selected model (Table 1).

Using the information system Excel we determine the correlation coefficients of the above rates (Table 2) to define the interdependence between the performance factor $Y$ (income) and $K$ (average cost of a unit of fixed assets), $Q$ (average cost of a unit of current assets) and $L$ (average salary of the workers).

Using the data in Table 2 and according to the [19, 20], we can conclude that the correlation analysis showed a very strong correlation between the logarithm of income and the logarithm of fixed assets as well as between the logarithm of income and the logarithm of salary costs. The correlation relationship between the logarithm of income and the logarithm of current assets is noticeable, but not strong. That is why it is quite reasonable to conduct a regression analysis in this study using only two factors - the average cost of a unit of fixed assets and the average cost of a unit of salary costs. Thus, the Cobb-Douglas function looks as follows

$$
Y=10^{\alpha_{0}^{*}} K^{\alpha_{1}} L^{\alpha_{2}} .
$$

The Microsoft Excel spreadsheet application was used to define the unknown parameters of the model and the model validity check. The outcomes of making a regression model are presented in Table 3 .

Table 1

\begin{tabular}{|c|c|c|c|c|}
\hline Year & $\begin{array}{l}\text { Logarithm } \\
\text { of income } \\
\text { variable }\end{array}$ & 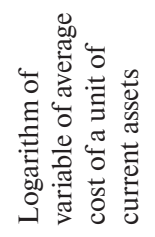 & 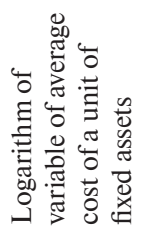 & $\begin{array}{c}\text { Logarithm } \\
\text { of variable } \\
\text { of average } \\
\text { salary }\end{array}$ \\
\hline 2010 & 3.063971007 & 2.19645254 & 1.7259116 & 0.447158 \\
\hline 2011 & 3.163906433 & 2.21853551 & 1.7895807 & 0.544068 \\
\hline 2012 & 3.301116846 & 2.09551804 & 1.8639174 & 0.5910646 \\
\hline 2013 & 3.46091287 & 2.16076856 & 1.9339932 & 0.6532125 \\
\hline 2014 & 3.475859971 & 2.19617619 & 1.9921115 & 0.6901961 \\
\hline 2015 & 3.463041475 & 2.09760433 & 2.0406023 & 0.7242759 \\
\hline 2016 & 3.464489547 & 2.05192392 & 2.0503798 & 0.770852 \\
\hline 2017 & 3.611298362 & 1.97680834 & 2.0982975 & 0.8195439 \\
\hline
\end{tabular}

Logarithms of operating rates of Rivnetelecombud LLC
It should be noted that the $R$-square characterizes the part of dependence of the performance factor $Y$ on the variables and demonstrates the adequacy of the model. In our case, the $R$-square (0.92798) is close to 1 , which confirms the high quality of this model; that is, regression efficiently describes the relationship between the performance factor $Y$ and the variables $K$ and $L$. The regression statistics, presented in Table 4, demonstrates an acceptable approximation of the regression equation to the equation of production function.

Thus, according to Table 4 , the coefficients of the regression equation are as follows

$$
\alpha_{0}^{*}=1.184 ; \quad \alpha_{1}=1.0172 ; \quad \alpha_{2}=0.3381 .
$$

Thus, taking into account the calculations, the equation (7) for the logarithm of the income function looks as follows

$$
\lg Y=1.1841+1.0172 \lg K+0.3381 \lg L .
$$

Having carried out the inverse transformation, we obtain the Cobb-Douglas function, so for the income function the equation can be presented as follows

$$
Y=15.276 \cdot K^{1.017} \cdot L^{0.338} \text {. }
$$

Fig. 2 illustrates the graph of the above function which is constructed using the information system software Mathcad. The graph clearly shows the dependence of the maximum value of the function $Y$ (income) on the parameters $K$ and $L$.

Optimization of relations between labor and assets in the information corporation on the basis of the use of Lagrange multipliers. On the basis of the condition, we find the optimum values for the average cost of a unit of fixed assets and the average salary of workers for the following years of development of the above company under the restrictions

$$
p_{1} K+p_{2} L=C,
$$

where $p_{1}$ is the number of units of fixed assets; $p_{2}$ is the number of workers; $C$ is general costs.

We study the possible values of the function parameters for the company "Rivnetelekombud" LLC. Based on the research outcomes, the predicted values for the first anticipated period will be as follows

$$
p_{1}=7 ; \quad p_{2}=20 ; \quad C=1050 .
$$

Substituting the values in the equation (9), the following correlation is obtained

$$
7 K+20 L=1050 .
$$

Analyzing various modifications of models we apply the Lagrange multiplier method which is used to solve mathematical programming problems - the method for finding the conditional extremum of the function $f(x)$, where $\mathrm{x} \in R^{n}$ is relative to $m$ constraints $\varphi_{i}(x)=0$.

The Lagrange function is constructed in the form of a linear combination of function $f$ and functions $\varphi_{i}$ with coefficients called Lagrange multipliers $-l_{i}$

Table 2

Table of coefficients of correlation of rates

\begin{tabular}{|l|c|c|c|c|}
\hline \multicolumn{1}{|c|}{ Parameter } & $\begin{array}{c}\text { Logarithm of } \\
\text { income variable }\end{array}$ & $\begin{array}{c}\text { Logarithm of variable of } \\
\text { average cost of a unit of } \\
\text { current assets }\end{array}$ & $\begin{array}{c}\text { Logarithm of variable of } \\
\text { average cost of a unit of } \\
\text { fixed assets }\end{array}$ & $\begin{array}{c}\text { Logarithm of variable of } \\
\text { average salary of a worker }\end{array}$ \\
\hline Logarithm of income variable & 1 & & & \\
\hline $\begin{array}{l}\text { Logarithm of variable of average } \\
\text { cost of a unit of current assets }\end{array}$ & -0.682859572 & 1 & 1 & \\
\hline $\begin{array}{l}\text { Logarithm of variable of average } \\
\text { cost of a unit of fixed assets }\end{array}$ & 0.962786018 & -0.741453911 & & \\
\hline $\begin{array}{l}\text { Logarithm of variable of average } \\
\text { salary of a worker }\end{array}$ & 0.957659285 & -0.770770922 & & 1 \\
\hline
\end{tabular}


Regression coefficients

\begin{tabular}{|l|c|}
\hline & Coefficients \\
\hline Y-crossing & 1.183998028 \\
\hline Variable $X_{1}$ & 1.017179394 \\
\hline Variable $X_{2}$ & 0.338072835 \\
\hline
\end{tabular}

Table 4

Regression statistics

\begin{tabular}{|l|l|}
\hline Multiple R & 0.963318422 \\
\hline R-square & 0.927982383 \\
\hline Normalized R-square & 0.899175336 \\
\hline Standard error & 0.058291312 \\
\hline
\end{tabular}

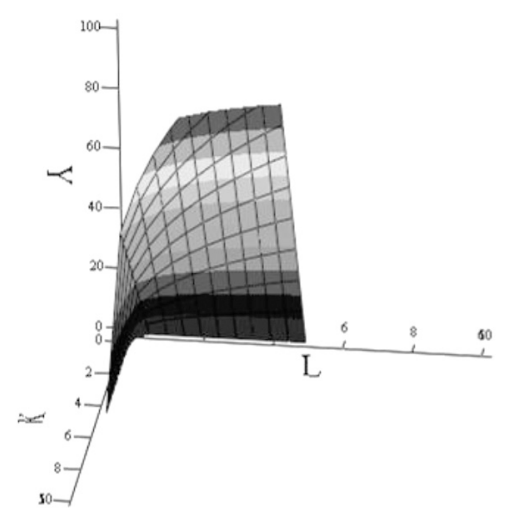

Fig. 2. Graph of the Cobb-Douglas function that illustrates the dependence of the income on the average cost of a unit of fixed assets and the average salary of the workers of "Rivnetelekombud" LLC (hundred dollars)

$$
L(x, l)=f(x)+\sum_{i=1}^{m} l_{i} \varphi_{i},
$$

where $l=\left(l_{1}, \ldots, l_{m}\right)$.

We construct a system of $n+m$ equations by setting the partial derivatives of the Lagrangian function $L(x, l)$ to zero with $x_{j}$ and $l_{i}$

If the resulting system has a solution for the parameters $x_{j}^{\prime}$, $l_{i}^{\prime}$ then the point $x^{\prime}$ can be a conditional extremum, that is, the solution to the initial problem. It should be noted that this condition is necessary.

We present the solution to the problem of finding a conditional extremum for a two-dimensional case.

We will assume that:

1) the function $f$ is continuously differentiated;

2) the function $\varphi$ is continuously differentiated, with partial derivatives which are not equal to zero at the same time, that is, the equation $\varphi(x, y)=0$ defines differentiable curve $S$ from the ordinary points on the plane $(x, y)$;

3 ) the curve $S$ does not pass through the points in which the gradient becomes zero.

In mathematical modeling we use the Lagrange function which depends on $x, y$ and $l$

$$
\operatorname{Lag}(x, y, l)=f(x, y)-l \cdot \varphi(x, y) .
$$

For the optimal solution to the Cobb-Douglas function (8), taking into account the given restrictions (9), we construct the Lagrange function

$$
\operatorname{Lag}(K, L, l)=10^{\alpha_{0}^{*}} K^{\alpha_{1}} L^{\alpha_{2}}-l\left(p_{1} K+p_{2} L-C\right),
$$

where $l$ is the Lagrange coefficient.
Thus, the necessary condition for its extremum is being equal to zero $\nabla L\left(x_{0}, y_{0}, l_{0}\right)=0$.

According to the rules of differentiating, the function is presented as follows

$$
\left\{\begin{array}{l}
\frac{\partial f}{\partial x}-l \cdot \frac{\partial \varphi}{\partial x}=0 \\
\frac{\partial f}{\partial y}-l \cdot \frac{\partial \varphi}{\partial y}=0 \\
-\varphi(x, y)=0
\end{array}\right.
$$

In the resultant system the first two equations are equivalent to the required condition of the local extremum, and the third one is the equation $\varphi(x, y)=0$. From the latter one can find a solution, meanwhile $l \neq 0$, because otherwise the gradient of function $f$ turns into zero at the point $\left(x_{0}, y_{0}\right) \in S$, which contradicts the assumption.

To determine the optimum of this function, it is necessary to differentiate it by the variables $K$ and $L, l$. We obtain

$$
\left\{\begin{array}{l}
\frac{\partial L a g}{\partial K}=10^{\alpha_{0}^{*}} \alpha_{1} K^{\alpha_{1}-1} L^{\alpha_{2}}-l p_{1}=0 \\
\frac{\partial L a g}{\partial L}=10^{\alpha_{0}^{*}} \alpha_{2} K^{\alpha_{1}} L^{\alpha_{2}-1}-l p_{2}=0 . \\
p_{1} K+p_{2} L=C
\end{array}\right.
$$

We substitute the values obtained in previous calculations related to $\alpha_{0}^{*}, \alpha_{1}, \alpha_{2}$, as well as the values $p_{1}, p_{2}, C$ in the system of equations (10). We obtain the following system of equations

$$
\left\{\begin{array}{l}
15.276 \cdot 1.017 \cdot K^{0.017} \cdot L^{0.338}-7 l=0 \\
15.276 \cdot 0.338 \cdot K^{1.017} \cdot L^{-0.662}-20 l=0 . \\
7 K+20 L=1050
\end{array}\right.
$$

Taking into account the complexity and scale of calculations of the system of equations, the Mathcad software was used.

Based on the calculations we obtain the following values of the average cost of a unit of fixed assets $K=112.583$, the average salary of workers' $L=13.096$, Lagrange coefficient $l=5.787$.

Consequently, further optimal functioning of the company "Rivnetelekombud" LLC requires the use of cheaper fixed assets with an average cost of 112.583 hundred dollars; in terms of human resources, it is necessary to hire more skilled workers with higher salaries, the average of 130.96 hundred dollars. Thus, in the next period the income will be as follows

$$
Y=15.276 \cdot 112.583^{0.017} \cdot 13.096^{0.338} \text {. }
$$

The calculation of such dependence makes it possible to estimate the values of these parameters, under which the income function reaches the maximum and will increase to 4.446 hundred dollars.

Therefore, it can be concluded that the outcomes of the multi-stage model are adjusted for determining not only on the basis of statistics, but also in the calculated prediction, which provides greater opportunities to manage the investment process by constructing a strategic plan in relation to the results of the prediction.

Conclusions. The results of the study demonstrate how the resources in the information company should be redistributed. As we have studied an information company, it appreciates the intellectual work of highly trained IT specialists. Therefore, the study implies the need for an information company to hire highly paid specialists, which can be ensured by reducing the costs of fixed capital.

Production functions are quite often used to determine production optima. The optimal production volume was estimated using this function. However, unlike our problem, the above problem explains additionally by means of estimation of the maximum of probability the difference between the actual 
and the optimum volume of production, and relevant conclusions are made regarding the improvement of the state of white honey production. The same goal of improving production is set in our problem. Thus, the problems are similar in terms of achieving the goal. However, the methods for achieving it are somewhat different.

Thus, based on the results of the research, we can state that optimization of the corporations' expenditure in the informational and institutional environment requires establishing the system of management and retraining of the personnel. The research also showed that there is a direct correlation between the corporation's profitability and salary costs. The employees' salary must constitute at least $\$ 520$ subject to indexation. Due to the need to match work with salary, it is necessary to employ more skilled employees in the telecommunications industry. The employment of highly skilled labor force in the information and communication sphere will increase the competitiveness of the company. We have examined the specific case of a telecommunications company. But the methodology of problem solving can be used by managers of other business units to increase their competitiveness by identifying reserves to further improve the performance of the company. It should be also noted that the control over the cost of fixed assets should follow the achievement of the strategic objectives of the company.

\section{References.}

1. Bilan, Y., Nitsenko, V., Ushkarenko, I., Chmut, A., \& Sharapa, O. (2017). Outsourcing in international economic relations. Montenegrin Journal of Economics, 13(3), 175-185. https://doi.org/10.14254/1800-5845/2017.13-3.14.

2. Kleyn, J., Arashi, M., \& Bekker, A. (2017). Preliminary testing of the Cobb-Douglas production function and related inferential issues. Communications in statistics-simulation and computation, 46(1), 469-488. https://doi.org/10.1080/0361091 $\underline{8.2014 .968724}$

3. Shen, Z., Hassani, A., \& Shi, Q. (2016). Multi-objective time-cost optimization using Cobb-Douglas production function and hybrid genetic algorithm. Journal of Civil Engineering and Management, 22(2), 187-198. https://doi.org/10.3846/13 923730.2014.897966.

4. Danyliuk, V., Riepina, I., Shafalyuk, O., Kovylina, M., \& Nitsenko, V. (2020). Functional and investment strategies of technical development of enterprises. Naukovyi Visnyk Natsionalnoho Hirnychoho Universytetu, (3), 115-121. https://doi. org/10.33271/nvngu/2020-3/115.

5. Bilan, Y., Zos-Kior, M., Nitsenko, V., Sinelnikau, U., \& Ilin, V. (2017). Social component in sustainable management of land resources. Journal of Security and Sustainability, 7(2), 107-120. https://doi.org/10.9770/issi.2017.7.2(9).

6. Latysheva, O., Rovenska, V., Smyrnova, I., Nitsenko, V., Balezentis, T., \& Streimikiene, D. (2020). Management of the sustainable development of machine-building enterprises: a sustainable development space approach. Journal of Enterprise Information Management. https://doi.org/10.1108/JEIM-122019-0419.

7. Kaleta, A., Radomska, J., \& Soloducho-Pelc, L. (2018). The relationship between the approach to strategic management and innovativeness in companies of various sizes. Argumenta oeconomica, 40(1), 203-224. https://doi.org/10.15611/aoe.2018.1.09. 8. Cheng, M. L., \& Han, Y. (2014). A modified Cobb-Douglas production function model and its application. IMA Journal of Management Mathematics, 25(3), 353-365. https://doi. org/10.1093/imaman/dpt012.

9. Nitsenko, V., Mardani, A., Streimikis, J., Ishchenko, M., Chaikovsky, M., Stoyanova-Koval, S., \& Arutiunian, R. (2019). Automatic Information System of Risk Assessment for Agricultural Enterprises of Ukraine. Montenegrin Journal of Economics, 15(2), 139-152. https://doi.org/10.14254/18005845/2019.15-2.11.

10. Lin, Yu., Deng, N., \& Gao, H. (2018). Research on technological innovation efficiency of tourist equipment manufac- turing enterprises. Sustainability, 10(12), 4826. https://doi. org/10.3390/su10124826.

11. Stijepic, D. (2017). An argument against Cobb-Douglas production functions (in multi-sector growth modeling). Economics Bulletin, 37(2), 1143. https://doi.org/10.2139/ssrn.2610734.

12. Ungerman, O., Dedkova, Ja., \& Gurinova, K. (2018). The impact of marketing innovation on the competitiveness of enterprises in the context of industry 4.0. Journal of competitiveness, 10(2), 132-148. https://doi.org/10.7441/joc.2018.02.09. 13. Olejarz, T., Nitsenko, V., Chukurna, O., \& Mykhailova, M. (2018). Evaluation of factors influencing labour performance of machine-building enterprises in mining industry. Naukovyi Visnyk Natsionalnoho Hirnychoho Universytetu, (1), 154-162. https://doi.org/10.29202/nvngu/2018-1/2.

14. Donato, M. B. (2016). Generalized Lagrange multiplier rule for non-convex vector optimization problems. Proceedings of the royal society of edinburgh section a-mathematics, 146(2), 297-308. https://doi.org/10.1017/S0308210515000463. 15. Alropyab, E.T., Desoukia, N.E., \& Alnafissac, M.A. (2019). Economics of technical efficiency in white honey production: Using stochastic frontier production function. Saudi Journal of Biological Science, 26(7), 1478-1484. https://doi. org/10.1016/j.sjbs.2019.09.029.

16. Boshkov, T., \& Drakulevski, L. (2017). Strategic and Finance Management - Determining Factors for the Success of the Companies in the Business World. Quality-access to success, 18(157), 119-123.

17. Huang, H. (2017). Lagrange multiplier rule for nonconvex set-valued optimization problem. Pacific Journal of Optimization, 13(3), 403-419.

18. Chukurna, O., Nitsenko, V., Kralia, V., Sahachko, Y., Morkunas, M., \& Volkov, A. (2019). Modelling and Managing the Effect of Transferring the Dynamics of Exchange Rates on Prices of Machine-Building Enterprises in Ukraine. Polish Journal of Management Studies, 19(1), 117-129. https://doi. org/10.17512/pjms.2019.19.1.09.

19. Chavez, C.E. D. (2018). Gerencia cuántica como plataforma estratégica de la servucción en empresas privadas. Revista cicag, 15(2), 108-132.

20. Sun, G., \& Xia, W. (2016). Evaluation method for innovation capability and efficiency of high technology enterprises with interval-valued intuitionistic fuzzy information. Journal of intelligent \& fuzzy systems, 31(3), 1419-1425. https://doi. org/10.3233/IFS-162208.

\section{Оптимізація співвідношення робочої сили та активів у контексті підвищення ефективності функціонування міжнародної інформаційної компанії}

\author{
О. М. Сазонець ${ }^{1}$, 3. В. Лось ${ }^{2}$, I. В. Перевозова ${ }^{3}$, \\ П. В. Самойлов ${ }^{2}$ Ю. О. Жаданова
}

$1-$ Університет митної справи та фінансів, м. Дніпро, Україна, е-mail: onsazonets@gmail.com

2 - Національний університет водного господарства та природокористування, м. Рівне, Україна

3 - Івано-Франківський національний технічний університет нафти і газу, м. Івано-Франківськ, Україна 4 - Одеська національна академія зв'язку імені О. С. Попова, м. Одеса, Україна

Мета. Дослідження впливу факторів виробництва на ефективність роботи інформаційної компаніі.

Методика. У ході дослідження були застосовані такі методи: теоретичне узагальнення (для висвітлення теоретичних і методологічних основ виробничих функцій), індукція, дедукція (для вивчення діяльності корпорацій), системний підхід (для побудови алгоритму визначення оптимальних значень середньої вартості одиниці основних виробничих засобів, оборотних активів і середньої 
заробітної плати), графічний метод (з метою наочного подання), математичне моделювання (для створення моделі оптимізації управління видатками корпорації).

Результати. У результаті застосування математичного апарату з>ясовано, що для забезпечення максимального прибутку оптимальним для інформаційної компанії $€$ наявність основних виробничих засобів на суму 112583 доларів з оплатою персоналу в середньому 13096 доларів на одного фахівця з урахуванням індексаціі.

Наукова новизна. Запропоновано алгоритм визначення оптимальних значень середньої вартості одиниці основних виробничих засобів, оборотних активів і середньої заробітної плати. Зроблена модель оптимізації управління видатками корпорації з використанням виробничої функції Кобба-Дугласа й теорії мультиплікаторів Лагранжа. Аналіз отриманої залежності дозволяє досягти оптимального значення цих параметрів, за яких функція доходу досягає максимуму.

Практична значимість. Представлені методи вирішення проблеми можуть бути використані для підвищення конкурентоспроможності компанії шляхом визначення резервів для подальшого вдосконалення бізнесу.

Ключові слова: оптимізачія, ефективність, виробнича функція, інформаційна компанія, багатоступенева модель

\section{Оптимизация соотношения трудовых ресурсов и активов в контексте повышения эффективности функционирования международной информационной компании}

\section{О. Н. Сазонеи ${ }^{1}$, З. В. Лось , И. В. Перевозова П. В. Самойлов ${ }^{2}$ Ю. А. Жаданова ${ }^{4}$}

1 - Университет таможенного дела и финансов, г. Днепр, Украина, e-mail: onsazonets@gmail.com

2 - Национальный университет водного хозяйства и природопользования, г. Ровно, Украина

3 - Ивано-Франковский национальный технический университет нефти и газа, г. Ивано-Франковск, Украина 4 - Одесская национальная академия связи имени А. С. Попова, г. Одесса, Украина
Цель. Исследование влияния факторов производства на эффективность информационной компании.

Методика. В ходе исследования применялись следующие методы: теоретическое обобщение (для освещения теоретических и методологических основ производственных функций), индукция, дедукция (для изучения деятельности корпораций), системный подход (для построения алгоритма определения оптимальных значений средней стоимости единицы основных производственных средств, оборотных средств и средней заработной платы), графический метод (для наглядного представления), математическое моделирование (для построения модели оптимизации управления расходами корпорации).

Результаты. В результате применения математического аппарата выяснилось, что для обеспечения максимальной прибыли оптимальным для информационной компании является наличие основных производственных средств на сумму 112583 долларов с оплатой персонала в размере 13096 долларов в среднем за одного специалиста с учетом индексации.

Научная новизна. Предложен алгоритм определения оптимальных значений средней стоимости единицы основных производственных средств, оборотных средств и средней заработной платы. Создана модель оптимизации управления расходами корпорации с использованием производственной функции Кобба-Дугласа и теории множителей Лагранжа. Анализ полученной зависимости позволяет достичь оптимального значения этих параметров, при котором функция дохода достигает максимума.

Практическая значимость. Представленные методы решения проблемы могут быть использованы для повышения конкурентоспособности компании за счет определения резервов дальнейшего улучшения бизнеса.

Ключевые слова: оптимизация, эффективность, производственная функция, информационная компания, многоступенчатая модель

Recommended for publication by I. V. Taranenko, Doctor of Economic Sciences. The manuscript was submitted 30.04.20. 